\title{
Columnar joints in the Patiño Formation sandstones, Eastern Paraguay: a dynamic interaction between dyke intrusion, quartz dissolution and cooling-induced fractures
}

\author{
1 Escola de Artes, Ciências e Humanidades, Universidade de São Paulo, Rua Arlindo Bétio 1000, 03828-080 São Paulo, Brasil.Email:vvf@usp.br \\ 2 Instituto de Geociências, Universidade de São Paulo, Rua do Lago 562, 05508-080 São Paulo, Brasil. \\ 3 Instituto Geológico, Secretaria do Meio Ambiente, Av. Miguel Estéfano 3900, 04301-903 São Paulo, Brasil.
}

The Patiño Formation sandstones, which crop out in Areguá neighborhood in Eastern Paraguay and show columnar joints near the contact zone with a nephelinite dyke, have as their main characteristics the high proportion of syntaxial quartz overgrowth and a porosity originated from different processes, initially by dissolution and later by partial filling and fracturing. Features like the presence of floating grains in the syntaxial cement, the transitional interpenetrative contact between the silica-rich cement and grains as well as the intense fracture porosity are strong indications that the cement has been formed by dissolution and reprecipitation of quartz from the framework under the effect of thermal expansion followed by rapid contraction.

The increase of the silica-rich cement towards the dyke in association with the orthogonal disposition of the columns relative to dyke walls are indicative that the igneous body may represent the main heat source for the interstitial aqueous solutions previously existing in the sediments. At macroscopic scale, the increasing of internal tensions in the sandstones is responsible for the nucleation of polygons, leading to the individualization of prisms, which are interconnected by a system of joints, formed firstly on isotherm surfaces of low temperature and later on successive adjacent planes towards the dyke heat source.

\section{Introduction}

In spite of the fact that the first reports on the geology of Paraguay date back to the beginning of the $18^{\text {th }}$ century, the occurrence of sandstones with columnar joints in the Areguá neighborhood has been only subject of reference in the work of Eckel (1959). It represents a valuable contribution to the exact location and description of the outcrops, although a more specific discussion on the origin of the columns is missing.
Several other articles on Paraguayan geology have been later published by the national literature, but no attention has been paid to those structures. The first helpful contribution to a better knowledge of the Areguá columnar sandstones is due to the paper released by Arribas and Latorre (1982) describing some of their general aspects such as mineralogical composition, geometric relationships among the columns and forming process.

Therefore, the available information on the Areguá geological feature is still insufficient and a systematic and detailed research concerning its spatial distribution, petrographic and geometric aspects remains to be done. On the other hand, most of the papers in the international literature preferentially focus upon the study of columnar joints associated with extrusive and intrusive igneous bodies, especially those of basaltic composition. Some of these investigated occurrences turned out to be classical examples of that structure and are well-known tourist spots like Giant's Causeway in Ireland and Devil's Postpile in California, USA.

Despite the progress observed during the last two decades in the studies of the type of material and the geological conditions in which these structures are formed (dykes, plugs, flows, pyroclasts, volcanic necks), their origin and evolution remain object of great scientific interest, mainly the prismatic pattern of the joints displaying symmetrical and dominantly hexagonal planes. It should be noted that references to columnar sandstones in the literature are also scarce.

Thus, considering the present lack of information, a work has been carried out aiming at a better understanding of the processes that contributed to the formation of the Areguá columnar sandstones.

\section{Geological setting}

Since the early publications by Harrington (1950), Eckel (1959), and Putzer (1962), the Ypacaraí Graben has been considered the most prominent structural feature of Eastern Paraguay. This tectonic valley of steep flanks, about $90 \mathrm{~km}$ long and extending from NW to SE between Benjamin Aceval and Paraguarí, forms the western segment of the Asunción Rift of Cretaceous age (Figure 1). One third of the northern portion of the graben is covered by the Ypacaraí Lake -15 to $20 \mathrm{~km}$ long, 5 to $8 \mathrm{~km}$ wide and an average depth of $3 \mathrm{~m}-$ located about $47 \mathrm{~km}$ from Asunción. It is nowadays one of the main tourist attractions in Paraguay.

From the tectonical point of view, at least two events have contributed to the present shape of the regional relief. The first one, of Cretaceous age, is related to the extensional tectonic regime responsible for the installation of the Asunción Rift and it is characterized by expressive alkaline potassic magmatism (Comin-Chiaramonti et 


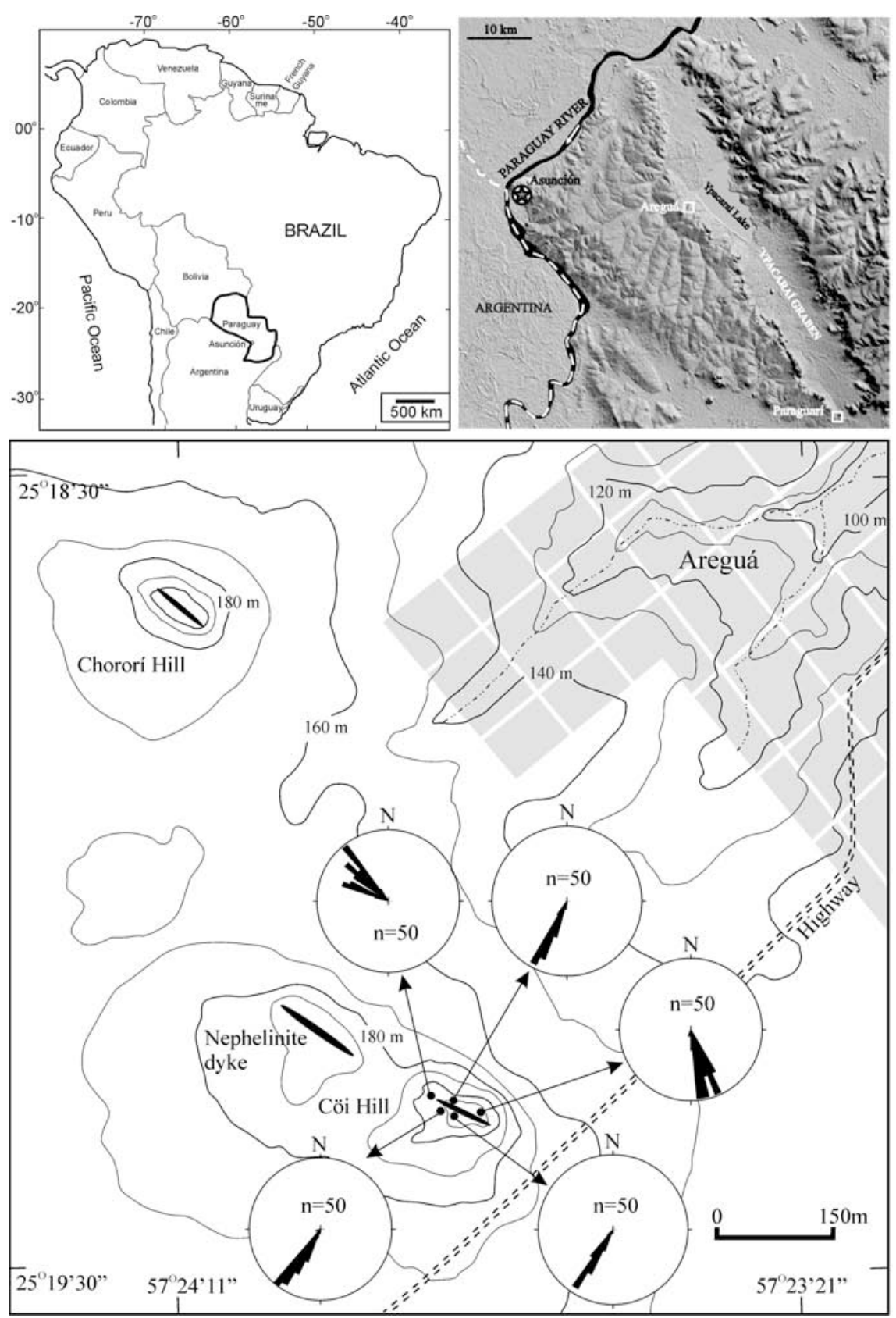

Figure 1 Sketch-map showing the location of the Ypacarai Graben and the orientation of the columnar joints in sandstones of the Patiño Formation near the Aregua village (Cöi and Chorori hills; dykes not in scale). Inset: rose diagrams for dip directions of the column axes ( $n=$ number of measurements).

al., 1997; Velázquez et al., 1998), widely distributed over the central segment of the rift. The second event started in the Paleogene and, until the present day, continues to provoke discrete seismic movements of low amplitude in the region (Berrocal and Fernandes, 1996). This deformation phase has been accompanied by the intrusion of dykes, plugs, and necks of ultra-alkaline sodic rocks of Paleocene age belonging to the Asunción Province (Comin-Chiaramonti et al., 2007). According to Riccomini et al. (2001), the second event was probably of stronger intensity than the first, generating deep faulting and regional changes of the geothermal gradient and it also exerts some influence on the control of the terrigenous sedimentation of the Patiño Formation.

The most impressive outcrops of Cenozoic sediments of the Patiño Formation are found along the southern border of the Ypacaraí Graben, unconformably overlying the Silurian deposits, between the cities of Asunción and Paraguarí This formation is mainly represented by alluvial fan and eolian terrigenous deposits as well as volcaniclastic sediments containing Paleocene alkaline rock fragments. According to Sallun (1999) and Riccomini et al. (1999), the terrigenous rocks include fanglomerates of large lithological diversity containing pebbles and boulders of Silurian sediments and of Cretaceous alkaline rocks set in a quartzose fine to coarse sandy matrix, poorly sorted. The eolian deposits are represented by moderately sorted reddish sandstones without interstitial matrix, showing metric sets of crossbedding. These deposits are restricted to the Asunción and Areguá regions and are locally cut by dykes, up to $3 \mathrm{~m}$ thick, of Paleocene alkaline rocks, which resulted in intense hydrothermal silicification close (some tens of meters) to the contact of the two lithologies and induced the formation of the columnar joints. The best expositions of these structures are found at the Cöi and Chororí hills, both occurrences herein investigated.

\section{Columnar joints}

The columnar joints of the Cöi and Chororí hills occur in reddish eolian sandstones, with the columns disposed orthogonally at both sides and terminations of the $0.8 \mathrm{~m}$ thick nephelinite dyke. Their inclination angle with the horizontal plane varies between $10^{\circ}$ and $60^{\circ}$, but values of $40-50^{\circ}$ are more frequent (Figure 2). The columns diameter ranges from 3 to $10 \mathrm{~cm}$ and their length can reach up to $15 \mathrm{~m}$. In transverse section, the polyg onal forms have four to seven sides, being the pentagonal form the most abundant type (Figure 3 ). Along the lateral faces of the prisms, parallel and regularly spaced fine bands (10 to $30 \mathrm{~mm}$ wide), with relief in steps, are disposed perpendicularly to the columns elongation (Figure 4). These bands are very similar to the "striae" described by Reiter et al. (1987) in columnar joints of basaltic flows and denominated by DeGraff and Aydin (1987) as plumose structure or as growth steps by Budkewitsch and Robin (1994). Each "stria" is interpreted by the latter authors as a result of successive increasing in the joint growth during the magma cooling, leading to the longitudinal development of the columns. The lateral contacts among the adjacent columns are characterized by triple junctions of the types $\mathrm{Y}$ and $\mathrm{T}$ (Figure 5).

\section{Mineralogical and textural characteristics}

The mineralogical assemblage of the sandstone cropping out at about $50 \mathrm{~m}$ from the intrusion (here referred as sandstone I) consists of more than $95 \%$ of resistates, which mainly include monocrystalline quartz ( 80 to $83 \%$ ), quartzite ( 2 to $3 \%$ ), chert ( 3 to $5 \%$ ), undifferentiated types of polycrystalline quartz (7 to 10\%) and blue elbaitic tourmaline (up to $0.5 \%$ ). In addition to the metastable constituents, feldspar (up to $2 \%$ ), opaque (1\%) and granitoid and schistose rock fragments (up to $1 \%$ ) are also observed. Based on these 

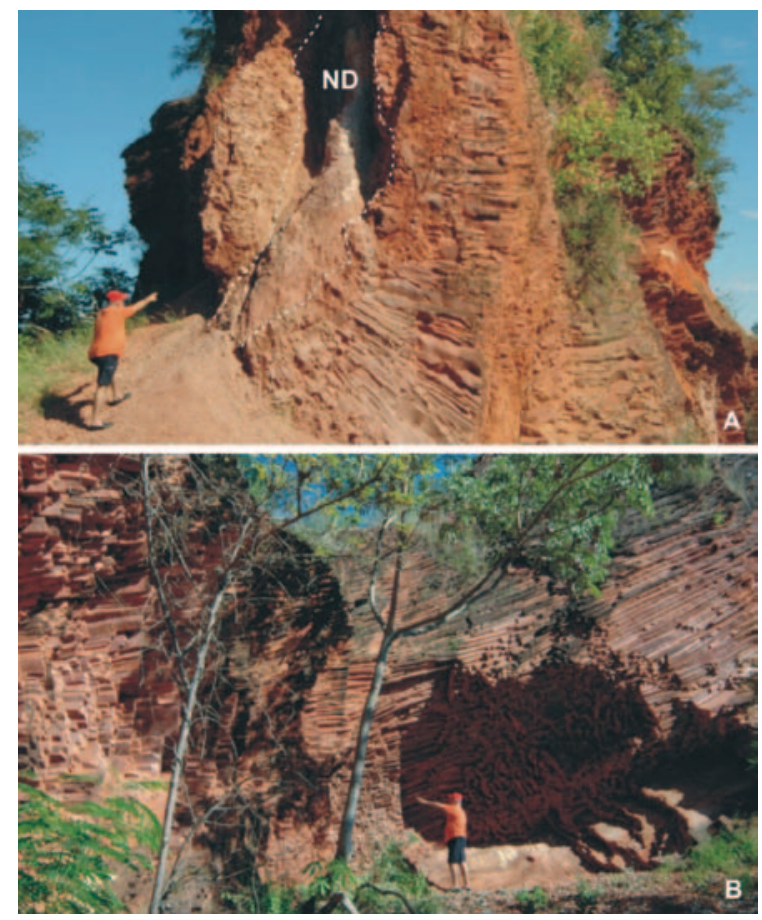

Figure 2 Orthogonal distribution of the sandstone columnar joints in relation to the altered and eroded nephelinite dyke (ND) (A) and detail of the almost horizontal parallel disposition of the columns (B) (Cöi hill).

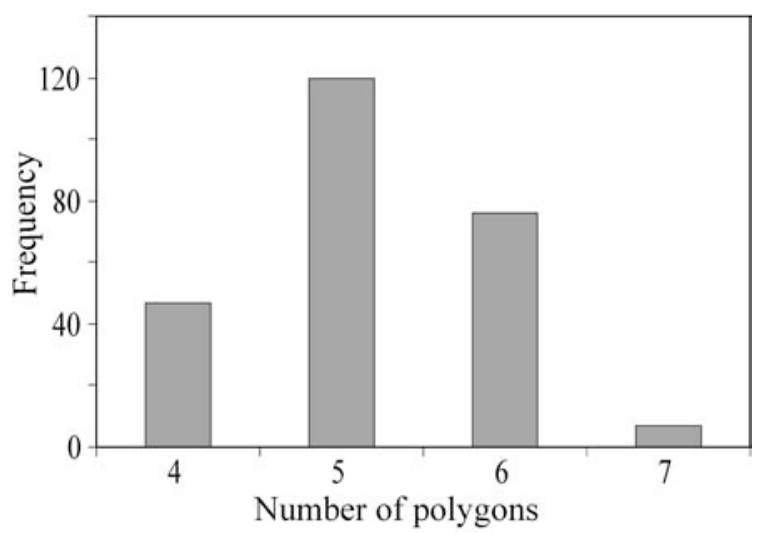

Figure 3 Histogram showing the predominance of pentagonal and hexagonal polygons in the Cöi hill columnar joints.

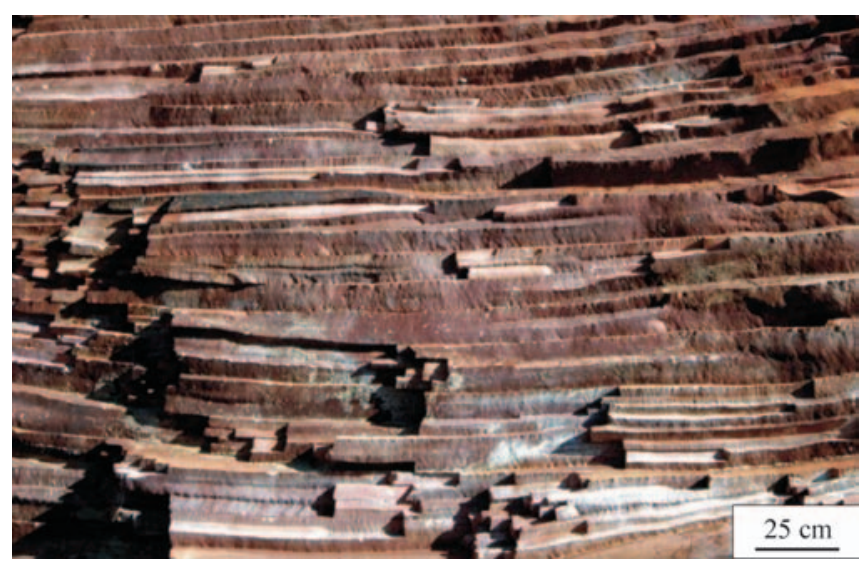

Figure 4 Transverse "striae" on the surface of the column faces (Cöi hill). It should be noted that the "striae" are found perpendicularly to the principal axis of each column.

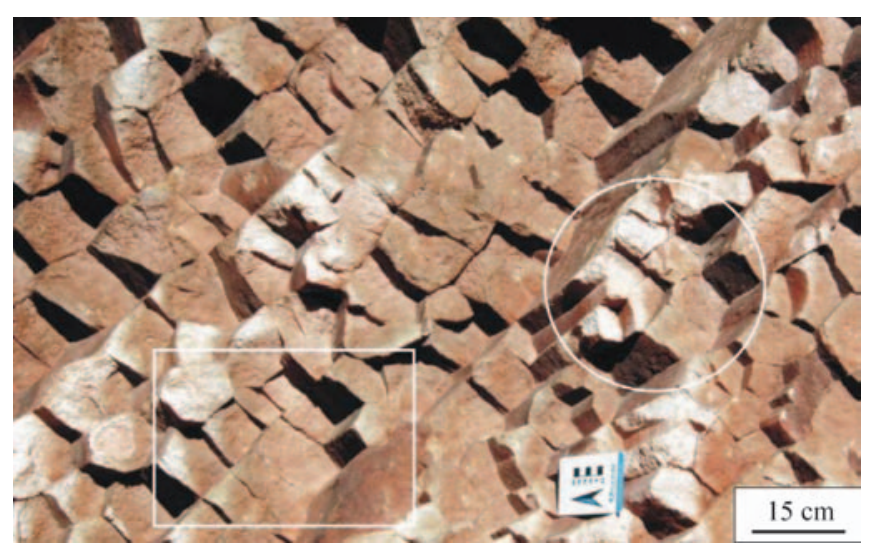

Figure 5 Oblique view of the columns at the same site of the figure $2 B$ showing two main types of junctions, $Y$-type (circle) and T-type (square).

values, the sandstone I is considered as mineralogically mature and is classified as quartz arenite. Concerning their texture, the framework exhibits fine to medium grain-size (177 to $500 \mu \mathrm{m}$, with the largest concentration in the interval $250-350 \mu \mathrm{m}$ ), poor to moderate granulometric sorting (graphic standard deviation between 0.9 to 1.1 phi), rounded to angular grains, dominantly sub-angular (40 to 60\%), and open packing arrangement. Most of the cement is made of filossilicate minerals displaying cryptocrystalline saccharoid texture (95\%), whose orange color is due to the association with colloidal iron oxides and/or hydroxides (Figure 6).

The most relevant characteristics of the sandstone close (from 0 to $15 \mathrm{~m}$ ) to the contact zone with the nephelinite dyke (here referred as sandstone II) are the absence of metastable constituents; the cloudy appearance of the quartz-rich cement, which is interpreted as due to the great amount of micrometric fluid inclusions, and the fabric of the rock showing floating grains inside the quartz-rich cement. The cement, containing more than $95 \%$ of quartz and including argillo-ferruginous material, forms a syntaxial overgrowth displaying sutured external boundary and irregular and embayed inner contour at the contact with the clastic nucleus. The invasive character of the zone contact between the grains and the quartz-rich cement (Figure 7) is indicative of the corrosive action exerted by hydrothermal solutions, clearly in disequilibrium with the framework.

The subrounded shape of the quartz grains in sandstone I is confirmed by SEM images (Figures 8A, B). The argillaceous cement occurs as rims 10 to $30 \mu \mathrm{m}$ thick and it is composed of aggregates of sub-polygonal to rounded plates, fine silt to clay in size (diameter of 1 to $5 \mu \mathrm{m}$ and thickness less than $1 \mu \mathrm{m}$, Figures 9A, B). The EDS analysis of the cement indicates a homogeneous composition rich in $\mathrm{Si}, \mathrm{Al}$ (stoichiometric rate $\mathrm{Si}: \mathrm{Al} 1.7$ ), and $\mathrm{O}$, with subordinate amounts of $\mathrm{Fe}$ (up to $1.7 \%$ ), $\mathrm{Na}$ (up to $0.5 \%$ ), and $\mathrm{K}$ (up to $0.3 \%$ ). These results, combined with the DRX data of the whole rock, point out to kaolinite as the dominant mineral. The well-defined boundaries of the plates and the disposition of some of them forming elongated arrangements (vermiform in shape) are indicative of its autigenic origin.

The SEM images of the sandstone II display quartz grains of nearly spheroidal forms and a surface texture marked by the presence of tiny pores and re-entrances (up to $5 \mu \mathrm{m}$ ). It represents the transitional passage from the smooth, but corroded, grain surface to the porous texture of the silica-rich cement. The gradual increasing in the amount of the intragranular pores and in the size of the reentrances, from the grain boundaries to the quartz overgrowth, give to the silica-rich cement a druse-like appearance. Images under high magnification of the cement indicate the existence of botryoidal and lepisphere aggregates (Figure 9B), a common shape of colloidal substances of low crystallinity, especially the "amorphous silica" with irregular repetition of the chrystobalite-trydimite reticule (opal-CT) (Carr and Fyfe, 1958; Fournier and Rowe, 1977). Considering the optical continuity between the cement and the clastic nucleus, a sec- 


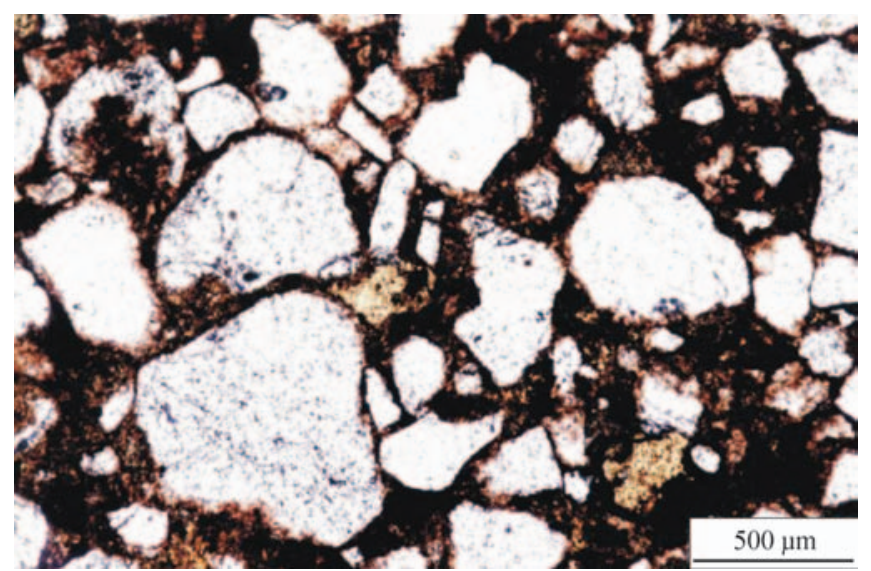

Figure 6 Thin section image of the sandstone I showing the textural open packing arrangement and the presence of cryptocrystalline filossilicatic cement.

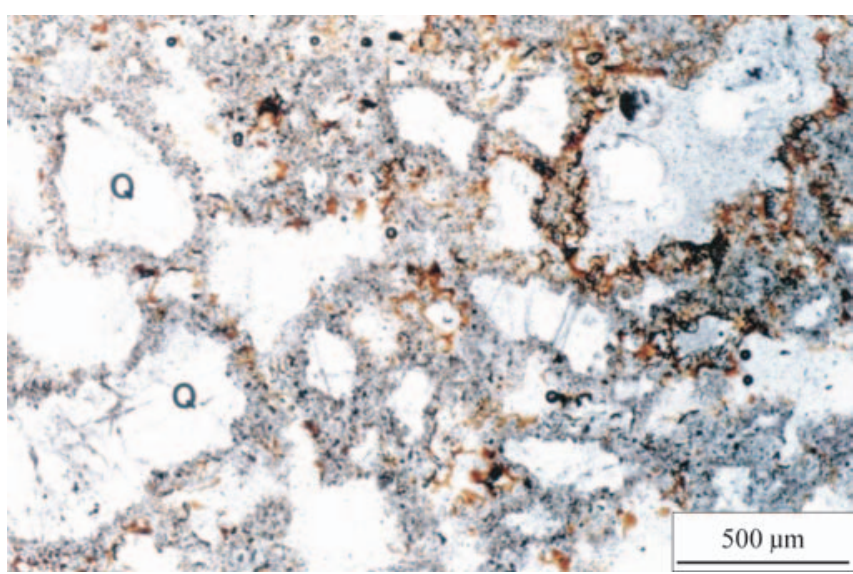

Figure 7 Thin section image of the sandstone II showing the corroded framework and the presence of tiny inclusions floating in the silica-rich cement (Q, quartz).

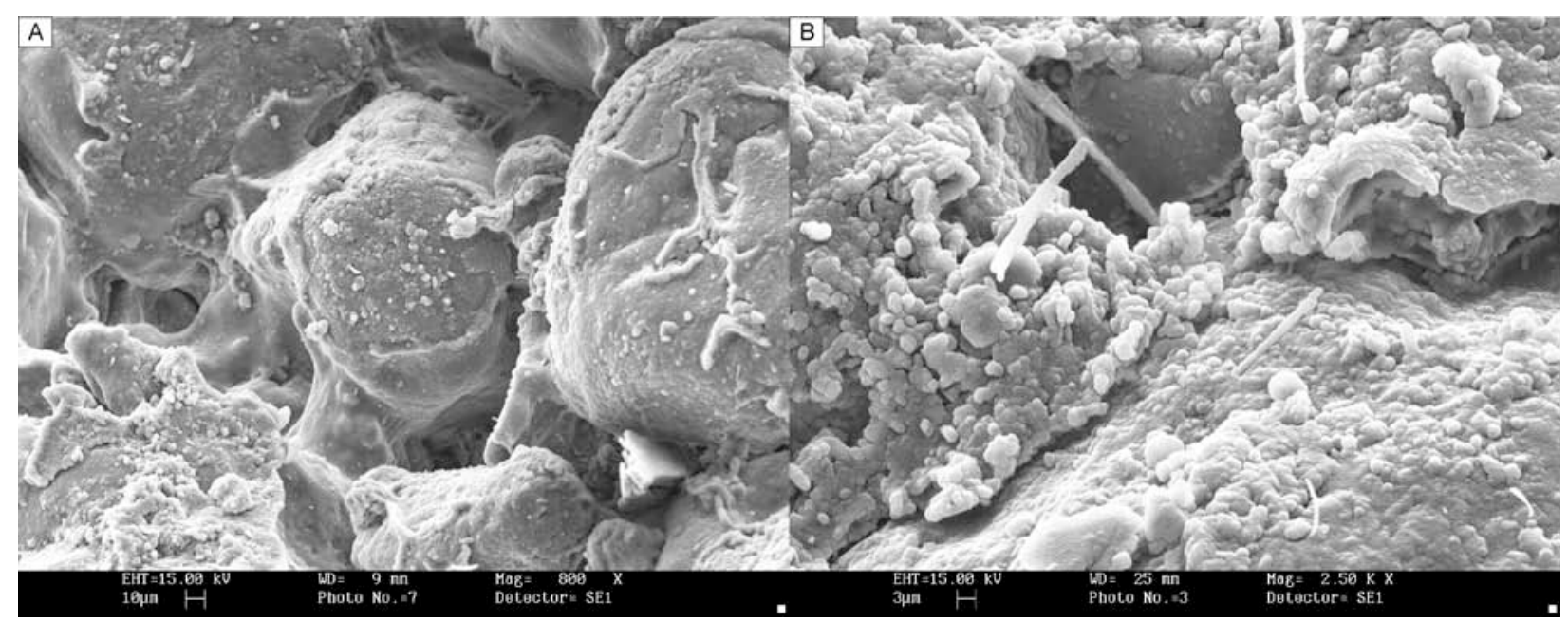

Figure 8 SEM images of the sandstone I: (A) rounded grains coated by filossilicatic cement and (B) detail of the cement rich in kaolinite plates.

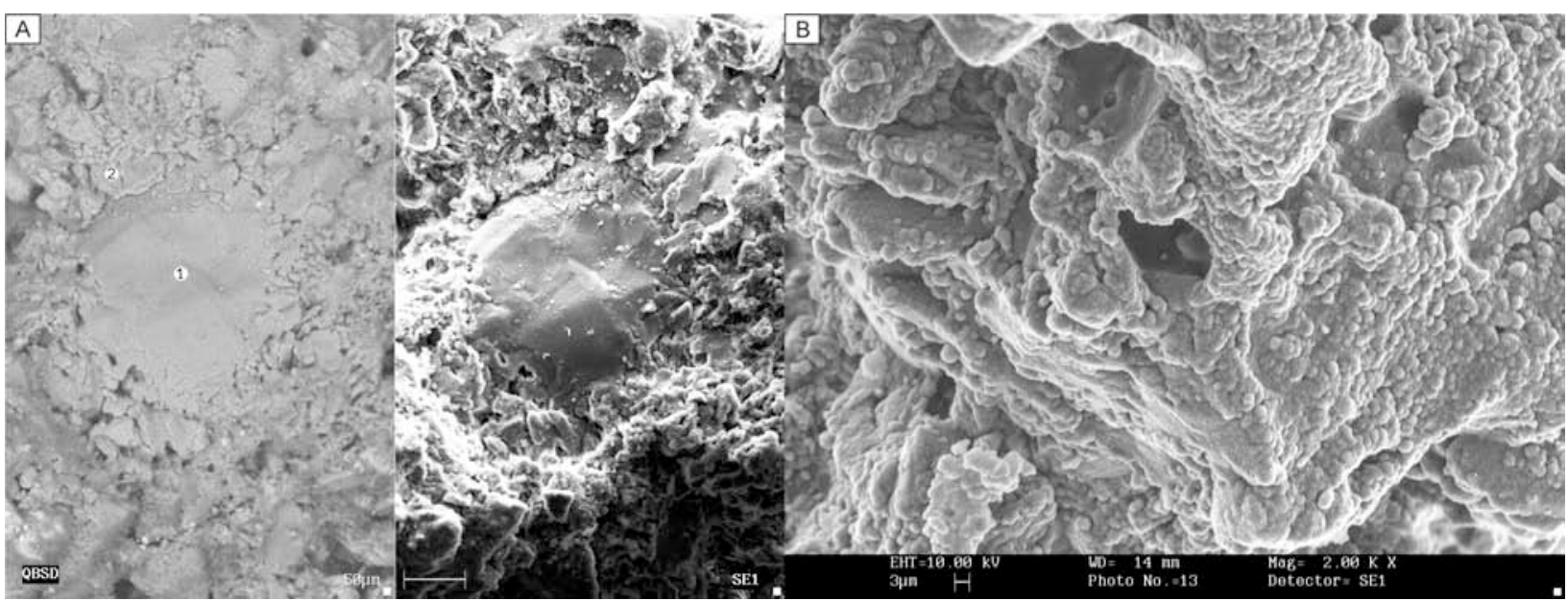

Figure 9 SEM images of the sandstone II: (A) corroded quartz grains (1) and microporous silica overgrowth (2) and (B) detail of the silicarich cement showing aggregates of botryoidal shape, a characteristic feature of colloidal silica of low crystallinity (opal-CT-like).

ondary quartz growth sensu stricto, perhaps formed from the preexistent silica of low crystallinity, is, therefore, a pseudomorphous of the opal-CT phase. Cathodoluminescent images confirm the contrasting difference of light emission colours of the quartz grains and the silica overgrowth (Figure 10).

The petrographic data and SEM analyses show that the transition from sandstone I to II, towards the contact zone of the intrusion, is followed by important mineralogical and textural changes such as the reduction of the porosity, the increasing of the syntaxial overgrowth proportion, the decreasing of the concentration of kaolinite in the cement and the gradual substitution of the type of porosity, from that originated from dissolution by that resulting from partial filling and fracturing. Furthermore, the quartz overgrowth replaces pseudomorphically the phase of low crystallinity. 


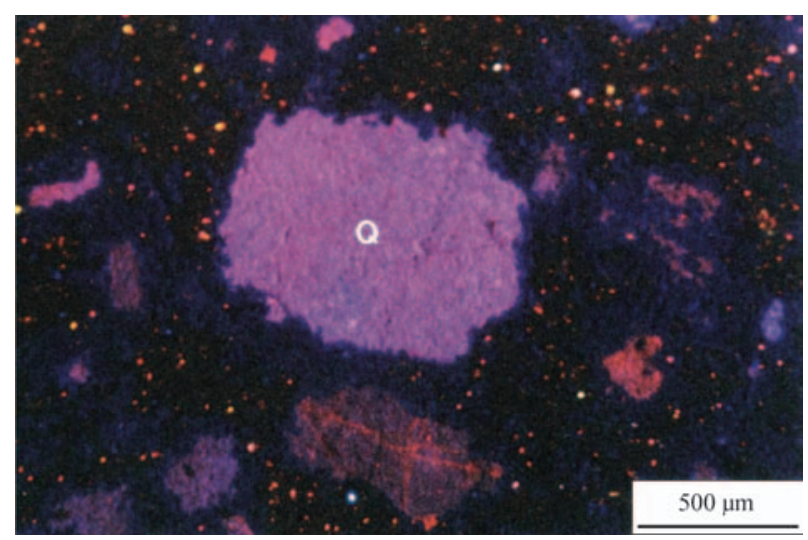

Figure 10 Cathodoluminescent images of the sandstone II, where the quartz grains of igneous origin can be distinguished by their luminescence colours (violet and red). The rim grains emit a blue color luminescence indicative of a neoformed origin.

\section{Discussion}

Polygonal prisms in unconsolidated sediments have been attributed to radial opposing internal tensions, which act at specific points of a plane or layer of the sedimentary deposit in a way to separate interfaces nearly equidistant from these points (Grabau, 1960). Among the polygonal forms that approximate to the ideal circular geometry of equidistance in the plane, the hexagonal is believed to be the most stable, i.e. the form that is capable to accommodate more appropriately the neighboring tension fields (Grabau, 1960). This juxtaposition is achieved through triple junctions of Y-type forming angles of about $120^{\circ}$. The most common mechanism for producing these tensions in sedimentary and diagenetic environments is by means of contraction as a response to one or more of the following factors: a) loss of fluids from the intergranular pores or crystalline reticules, b) crystallization or transformation of cements and c) cooling. In the particular case of Areguá, it is believed that all these factors have played some role.

The field observations indicate that the Areguá sandstone columns are disposed perpendicularly to the contact zone in relation to the dyke walls and extremities. The analysis of the prisms in traverse section reveals that during the propagation of the joints the prevailing of one intersection plane (Y-type or T-type) was determinant to define the geometric pattern of the polygons. Thus, in sites where the Y-type intersection was more frequent than the T-type one, pentagonal and hexagonal polygons have been formed, although in sites where the T-type intersection was predominant, tetragonal polygons with less isometric pattern have been generated (Figure 11).

Other important aspect in the morphological analysis of the columnar joints is the hexagonality index $\left(\mathrm{X}_{\mathrm{N}}\right)$, given by the mathematical expression:

$$
\mathrm{X}_{\mathrm{N}}=\sqrt{ }\left(f_{5}+f_{7}\right)+4\left(f_{4}+f_{8}\right)+9\left(f_{3}+f_{9}\right)+16 f_{10}+25 f_{11} \ldots \ldots \ldots
$$

where $f_{\mathrm{n}}$ expresses the fraction of $n$-side polygons in the set. This index determines the degree of maturity of the synchronic evolution of the joints for the most stable symmetry, i.e. the hexagonal pattern (Budkewitsch and Robin, 1994). Higher the index value, less correspondence does exist in relation to the ideal hexagonal pattern $\left(\mathrm{X}_{\mathrm{N}}=0\right)$. The histogram of Figure 3 illustrates the frequency of the number of faces for 250 measurements carried out in the Cerro Cöi columns. In an attempt to minimize the probability of a selective sampling, the data were colleted randomly in five different areas. The $\mathrm{X}_{\mathrm{N}}$ resulted to be equal to 0.97 , with an average value of 5.50 sides for polygon. This number is very close to that reported by Beard (1959) for the basaltic columns of Devil's Postpile, where $X_{N}$ is equal to 0.98 . In comparison with most of the basaltic joints, the Cöi hill sandstone columns show a moderately mature pattern, although far from the typically hexagonal pattern.

Three exclusive features of the sandstone II-floating grains in the syntaxial cement, transitional interpenetrative contact between cement and grains, and intense fracture porosity - are strong indications that the cement of these sediments has been formed by dissolution and reprecipitation of quartz from the framework under the effect of thermal expansion followed by rapid contraction.

In sandstone diagenesis, the most common favorable conditions for silica precipitation are the intense or continuous percolation of pore waters (seldom supersaturated in silica) and the advantage of additional amounts of silica in solution as given by strong or successive oscillation of water temperature (heating followed by cooling) and/or $\mathrm{pH}$ variation (increasing followed by decreasing) (Pettijohn et al., 1972). Under temperatures higher than $300^{\circ} \mathrm{C}$, the effects of increasing pressure and salinity became also very important factors for raising the quartz solubility and disposition of silica in pore waters (Fournier, 1985). The type of the precipitated silica depends on the velocity of the process leading to the fall of the solubility. A slow and gradual process, favored by a silica concentration slightly over the equilibrium saturation and under temperature less than about $180^{\circ} \mathrm{C}$, tends to precipitate chalcedony (Pettijohn et al., 1972; Fournier, 1985). On the other hand, a rapid process, with silica concentration instantaneously much over the equilibrium saturation, precipitates opal-CT (Chen and Marshall, 1982). Quartz is formed under moderate conditions of supersaturation (Crerar et al., 1981). Opal and chalcedony are susceptible to increase the temperature and pressure of pore waters during the burial mesodiagenesis and show the tendency of being gradually transformed into quartz (Fournier and Potter, 1982).

In the case of the Patiño Formation, the simple presence of quartz overgrowth in great amounts in the sandstone II seems to indicate the existence of special conditions governing silica solution and reprecipitation. These conditions could include the appropriate perco-

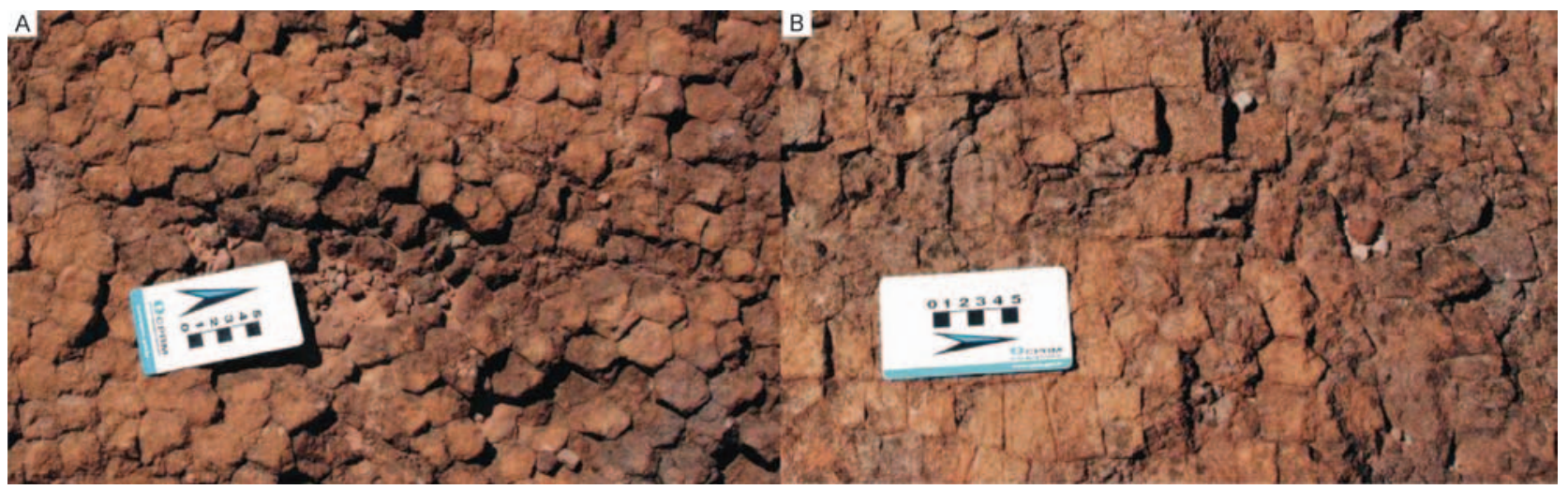

Figure 11 Orthogonal view of the columns. It should be noted that (A) the Y-type intersection, with angles of about $120^{\circ}$, gives origin to pentagonal and hexagonal polygons and $(B)$ the T-type intersection, with angles of about $90^{\circ}$, forms polygons dominantly tetragonal. 
lation of pore waters during the geological time (tens of millions of years) favored by the strong hydraulic gradient due to the regional topographic relief (fault scarps). Meanwhile, the textural characteristics of the sandstone II suggest that the initial silica-rich cement is composed of a low crystallinity phase, formed quickly in loco under conditions of intense dissolution and reprecipitation of quartz. The abundant presence of fluid trapped as inclusions strongly supports the action of that mechanism. The model involving a continuous percolation of fluids seems not to apply to this case, because it is unable to explain either the primary mineralogy or the texture of the grains floating in the cement in association with the fracture porosity. It becomes necessary to appeal for a hydrothermal event, which would be able to promote a rapid and localized process of quartz dissolution in addition to the abrupt increasing of temperature and/or $\mathrm{pH}$ in the pore waters. Under these conditions, the opal-CT would be the stable precursor phase for the silica.

The orthogonal disposition of the columns in relation to the nephelinite dyke, associated with the increasing of the silica-rich cement towards the igneous body, allow us to regard the intrusion as the main heat source for the interstitial aqueous solutions previously existing in the sandstones. The injection of magma with high temperature $\left(\sim 900^{\circ} \mathrm{C}\right)$ is thought to be responsible for the partial dissolution of quartz grains and consequent addition of silica to the interstitial liquid phase, from where it would be reprecipitated during the posterior cooling. Similar conditions were described by Summer and Ayalon (1995) for the columnar sandstones of Makhtesh Ramon, Israel.

The morphological similarity between the sandstone columns and those found in some basaltic flows permits to infer for the Areguá occurrence the same general processes used to explain the formation of such structure in the above igneous rocks: rapid cooling and severe thermomechanical contraction, leading to nucleation and propagation of the cracks.

Decrease in volume of sedimentary rocks is commonly accomplished by the grain size reduction during the thermal dissolution. This drastic change in volume is responsible for a "disequilibrium quite distant from the equilibrium" (sensu Prigogine) that demand a radical tree-dimensional rearrangement of the sediments both at macroscopic and microscopic scales. In the energy dissipation process that characterizes the formation of this new tree-dimensional arrangement (new equilibrium), the sediments are submitted to multidirectional tensions leading to an isometric pattern. At microscopic scale, this pattern is expressed by the high sphericity of the corroded grains found floating inside the silica-rich cement and homogeneously distributed. At macroscopic scale, the increasing of internal tensions in sedimentary rocks gives rise to the nucleation of polygons and leads to the individualization of prisms. These are interconnected by a system of joints, first acting on isotherm surfaces of less temperature and later on successive adjacent planes towards the dyke heat source. The initiation of the cracking process on the surface of lower isotherm and its posterior propagation towards the dyke is suggested by the arrangement and spacing of the growth steps along the column faces and by the increasing of the columns diameters towards the dyke. Therefore, the direction of the joint growth is perpendicular to the isotherms and parallel to the heat flow lines, as indicated by the orthogonal disposition of the sandstone columns in relation to the dyke (Figure 12).

The moderate maturity of the polygonal pattern, as suggested by the hexagonality index around 1, the cement habit typical of a precursor mineral of low crystallinity and the reduced diameters of the columns point to a relatively rapid cooling process when compared with the columnar joints in igneous bodies. The probable reason for this difference relates to the thermal gradient between the dyke and the sedimentary deposit, which is a short distance (few tens of meters).

Considering that the saturation fluid of the sedimentary deposit has been the main agent of heat transmission and transportation of solved silica and that the joints represent the main conductors for the fluid circulation, the relative rapidity and efficiency of heat dissipation in this case may be related to two factors: the low viscosity and

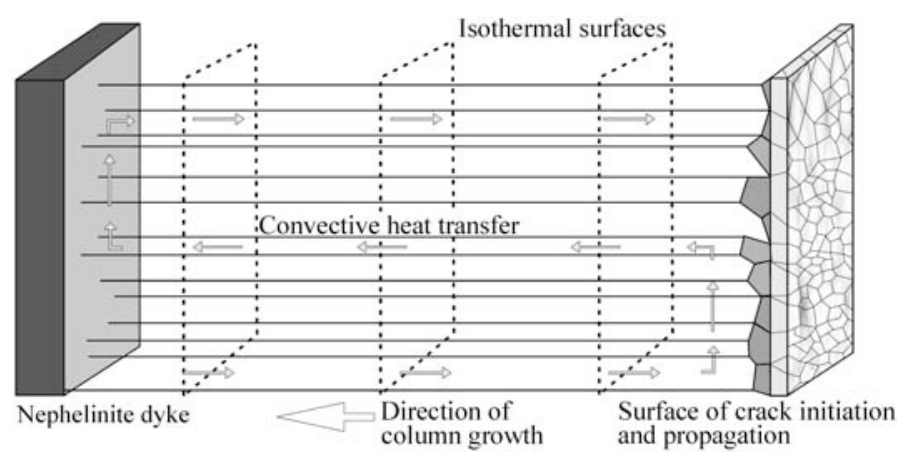

Figure 12 Idealized thermomechanical model, based on field observations and petrographic data, illustrating the relationship between the nephelinite dyke and the sandstone columnar junctions.

high mobility of the interstitial water and the efficient development of the columnar joints. Thus, the interstitial water, being more fluid than the magma, circulates easily through the sandstone intrusion system. Meanwhile, the mechanic behavior of the sandstones, getting close to brittle deformation, contributes to accelerate the formation of joints towards the main heat source. These two factors act simultaneously. As the pores are filled by precipitated silica, with the increasing of the consolidation degree of the sandstones, the expelled water migrates through pores and new opened joints, accelerating the cooling process and the columns formation. The high velocity of cooling helps the development of columns of short diameter and, hence, multiplies the conducts for the water migration. It is thus created a positive feedback in the cooling process. In this way, the mechanism responsible for the columnar joints in sandstones is somewhat different from the one suggested for the formation of similar joints in igneous rocks, where the cells of heat convection can act for a long time over all the extension of the plastic magmatic body.

\section{Conclusions}

The columnar joints of Areguá, located in the western segment of the Asunción Rift, Eastern Paraguay, occur in reddish eolian sandstones and are disposed orthogonally at both sides and terminations of the nephelinite dyke. Column ranges from 3 to $10 \mathrm{~cm}$ in diameter, reaching $15 \mathrm{~m}$ in length, and the polygonal forms have four to seven sides, being the pentagonal predominant. Parallel and regularly spaced fine bands with relief in steps occur perpendicularly to the columns elongation. In comparison with the basaltic joints, the sandstone columns of Areguá show a moderately mature pattern, far from the typically hexagonal pattern.

The textural characteristics of the sandstones near the nephelinite dyke, including the abundant presence of fluid trapped as inclusions, suggest that initial silica-rich cement is composed of a low crystallinity phase, formed quickly in loco under conditions of intense dissolution and reprecipitation of quartz. A hydrothermal event seems to be the most probable process to promote a rapid and localized dissolution of quartz in addition to the abrupt increasing of temperature and/or $\mathrm{pH}$ in the pore waters. The interstitial aqueous solutions in the sandstones were heated as consequence of magma injection causing partial dissolution of quartz grains, addition of silica to the interstitial liquid phase and further reprecipitation during cooling.

Rapid cooling and severe thermomechanical contraction lead to nucleation and propagation of the cracks. Increasing of internal tensions in the sandstone has caused the nucleation of polygons and consequent individualization of prisms interconnected by a system of joints. Joints acted firstly on isotherm surfaces of less temperature and later on successive adjacent planes towards the dyke heat source. 
Cracking initiated on the surface of lower temperature isotherm and propagated towards the dyke following heat flow lines.

The proposed mechanism for the origin of columnar joints in sandstones of Areguá, Eastern Paraguay, differs in terms of velocity from those admitted for the formation of similar features in igneous rocks, where the cells of heat convection can act for a long timeinterval over all the extension of the magmatic body.

\section{Acknowledgements}

This work was carried out with the financial support from Fapesp (Proc. 97/01210-4 and 01/10714-3) and CNPq (Brazil).

\section{References}

Arribas, A., and Latorre, C. O., 1982, El origen de la disyunción columnar en areniscas: caso de las cuarciarenitas de Areguá (República del Paraguay): Tecniterrae, v. 321, pp. 7-18.

Beard, C. N., 1959, Quantitative study of columnar jointing: Geological Society American Bulletin, v. 70, pp. 379-382.

Berrocal, J., and Fernandes, C., 1996, Seismicity in Paraguay and neighbouring regions, in Comin-Chiaramonti, P., and Gomes, C. B., eds., Alkaline magmatism in central-eastern Paraguay. Relationships with coeval magmatism in Brazil: São Paulo, Edusp/Fapesp, pp. 57-66.

Budkewitsch, P., and Robin, P. Y., 1994, Modelling the evolution of columnar joints: Journal of Volcanology and Geothermal Research, v. 59, pp. 219-239.

Carr, R. M. and Fife, W. S., 1958, Some observations on the crystallization of amorphous silica: American Mineralogist, v. 43, pp. 908-916.

Chen, C. T. and Marshall, W. L., 1982, Amorphous silica solubilities. Behavior in pure water and aqueous sodium chloride, sodium sulfate, magnesium chloride, and magnesium sulfate up to $350^{\circ} \mathrm{C}$ : Geochimica et Cosmochimica Acta, v. 46, pp. 279-287.

Comin-Chiaramonti, P., Cundari, A., Piccirillo, E. M., Gomes, C. B., Castorina, F., Censi, P., De Min A., Marzoli, A., Speziale, S. and Velázquez, V. F., 1997, Potassic and sodic igneous rocks from Eastern Paraguay: their origin from the lithospheric mantle and genetic relationships with the associated Paraná flood tholeiites: Journal of Petrology, v. 38, pp. 495-528.

Comin-Chiaramonti, P., Marzoli, A., Gomes, C.B., Milan, A., Riccomini, C., Velázquez, V.F., Mantovani, M.S.M., Renne, P., Tassinari, C.C.G. and Vasconcelos, P.M. 2007. The origin of Post-Paleozoic magmatism in Eastern Paraguay. Geological Society of America, Special Paper, 430:603-633.

Crerar, D. A., Axtmann, E. V. and Axtmann, R. C., 1981, Growth and ripening of silica polymers in aqueous solutions: Geochimica et Cosmochimica Acta, v. 45, pp. 1259ᄀ1266.

DeGraff, J. M., and Aydin, A., 1987, Surface morphology of columnar joints and its significance to mechanics and direction of joint growth: Geological Society of America, v. 99, pp. 605-617.

Eckel, E. B., 1959, Geology and mineral resources of Paraguay: a reconnaissance: Geological Survey Professional Paper, pp. 327.

Fournier, R. O., 1985, The behavior of silica in hydrothermal solutions: Reviews in Economic Geology, v. 2, pp. 45-59.

Fournier, R. O. and Potter, R. W. I., 1982, An equation correlating the solubility of quartz in water from $25^{\circ}$ to $900^{\circ} \mathrm{C}$ at pressures up to 10,000 bars: Geochimica et Cosmochimica Acta, v. 46, pp. 1969-1973.

Fournier, R. O., and Rowe, J. J., 1977, The solubility of amorphous silica in water at high temperatures and high pressures: American Mineralogist, v. 62, pp. 1052-1056.

Grabau, W. 1960, Principles of stratigraphy: New York, Dover Publication, Inc., pp. 777-779.

Harrington, H. J., 1950, Geología del Paraguay Oriental: Universidad de Buenos Aires Facultad de Ciencias Exactas, Físicas y Naturales, Contribución Científica Serie E Geología, v. 1, pp. 1-82.

Pettijohn, F. J., Potter, P. E., and Siever, R., 1972, Sand and sandstone: New York, Springer-Verlag, pp. 618.

Putzer, H., 1962, Die Geologie von Paraguay: Berlin-Nikolassee: Bornträger, pp. 182.

Reiter, M., Barroll, W. M., Minier, J. and Clarkson, G., 1987, Thermomechanical model for incremental fracturing in cooling lava flows: Tectonophysics, v. 142 , pp. 241-260.
Riccomini, C., Velázquez, V. F., Gomes, C. B., and Sallun, A. E. M., 1999, Cenozoic evolution of the western segment of the Asunción Rift, Eastern Paraguay: Jornadas Científicas sobre la Geología del Paraguay, San Bernardino, Paraguay, v. 1, pp. 2.

Riccomini, C., Velázquez, V. F., Gomes, C. B., 2001, Cenozoic lithospheric faulting in the Asunción Rift: Journal of South American Earth Sciences, v. 14 , pp. $625-630$

Sallun, A. E. M., 1999, Relações entre a tectônica e a sedimentação cenozóica na região do Graben de Ypacaraí (Rift de Assunção, Paraguai Oriental): Trabalho de Formatura, Universidade de São Paulo, Instituto de Geociências, Brasil, pp. 59.

Summer, N. S., and Ayalon, A., 1995, Dyke intrusion into unconsolidated sandstone and the development of quartzite contact zone: Journal of Structural Geology, v. 17, pp. 997-1010.

Velázquez, V. F., Riccomini, C., Gomes, C. B., Figueredo, L., and Figueredo, C., 1998, Relações tectônicas do magmatismo alcalino do Paraguai Oriental: Revista do Instituto Geológico, v. 19, pp. 41-48.

Victor Fernandez Velázquez is an Assistant Professor in the School of Arts, Sciences and Humanities of the University of São Paulo, Brazil. His principal studies involve the petrogenesis of the alkaline magmatism associated with the Paraná Basin, with particular attention for the Paraguayan and Bolivian occurrences. Additional research interests include the assessment of geological sites for geoconservation. He received his $P h D$ in petrology from the University of São Paulo in 1996.

Paulo Cesar Fonseca Giannini has worked as professor-researcher since 1988, initially in the Department of Geology of Paraná University (Brazil) and starting from 1997 in the Department of Sedimentary and Environmental Geology of the Institute of Geosciences, São Paulo University (Brazil). In this last institution, he obtained his Undergraduate (1982), Master (1987), Doctor (1993) and Associate (2007) degrees. His research has focused mainly on the facies and depositional dynamics of eolian depositional systems with special interest in mineralogy and petrography of their deposits.

Claudio Riccomini received his $P h D$ in Sedimentary Geology from the University of São Paulo in 1989. He works at the Department of Sedimentary and Environmental Geology of the Institute of Geosciences of the same university since 1986, where he is Full Professor. His current research is focused on tectonics and sedimentation, basin analysis and neotectonics in South America. He was President of the Brazilian Geological Society from 1993 to 1995 and from 1997 to 1999, and the President of the Brazilian Committee on Geological Sciences from 1993 to 1995.
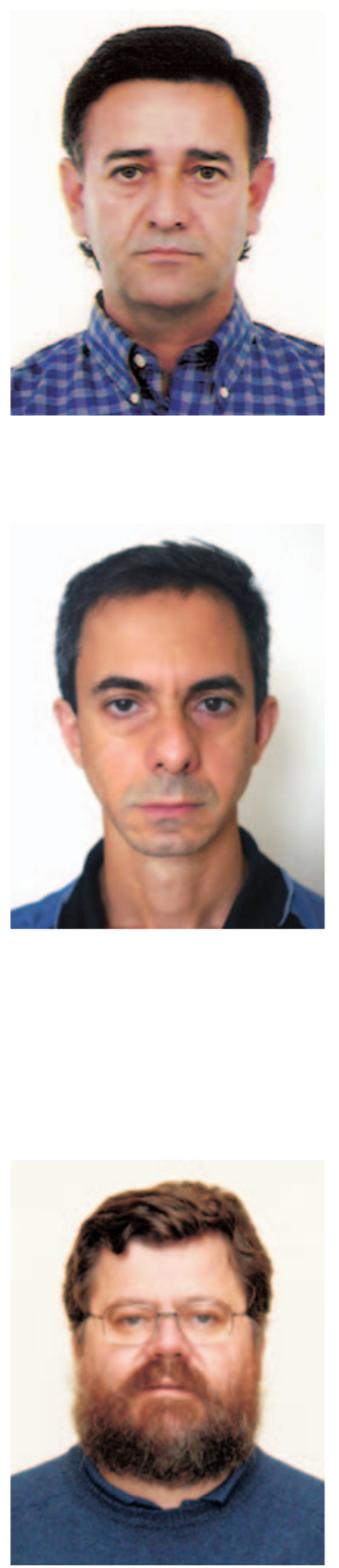